\title{
Effective Coaching Patterns for Cadets to Anticipate Violence Between Senior and Juniors
}

\author{
Jumardin \\ Politeknik Ilmu Pelayaran Makassar \\ Jl. Tentara Pelajar no.173, Makassar, telp: (0411) 3616975, 3614744, \\ 3622124, 3622207, fax: (0411) 3616974, (0411) 3628732 \\ jumardin@gmail.com
}

\begin{abstract}
The research is aimed find out to know whether the pattern of coaching that has been held at the Politeknik Ilmu Pelayaran Makassar has been running effectively or not. In addition, this study also finds out what characters the cadets have from the coaching styles that have been implemented in the PIP Makassar environment. This study uses a qualitative research method that produces and process of descriptive data such as interview transcripts, notes field, picture, photos, recordings and videos. The techniques use in selecting the subjects in this study was purposive sampling techniques. The research result of this is pattern of development during this already considered running effectively by cadets for mental shape cadets as a professional sailor. The cadets feel that they are used to the harsh conditions on the boat while sailing and the cadets feel that they are used to the harsh conditions on the boat while sailing. The characters obtained from the coaching patterns have been taking place at PIP Makassar have been considered by both cadets and alumni because they are able to shape cadets and alumni to become individuals who have tough character, have goodself-control and responsibility.
\end{abstract}

Keywords: Coaching Pattern, official school, cadets

\section{Introduction}

\subsection{Background}

Coaching Pattern formation of character in schools high is a key principal in the form of students or cadets be a human being that competitive, able to actualize themselves as positive for undergoing training, as well as able to provide contributions to various environment such as campus, local, as well as the Country.

At the point of this is the situation becomes vulnerable, the relationship hierarchical between senior and junior into strata that can only perform acts of violence on behalf embodiment of discipline. [16] More further explained Suyanto that victims of violence in case this junior cadet do not dare to report the case that happened to him because of fear of going to get treatment that is worse by seniors still feel threatened by seniors.

Some cases of violence or harassment that take attention of the public at whom the violence that led to the death which befell Amirullah Adityas Son (18 years ) a civil School of High Studies Sailing (STIP) in Jakarta. Son died after experiencing violence in the form of beatings on the part of the abdomen, chest, and the pit of the heart. Cases such is the case of the death of the three in institutions of education belongs to the Ministry of Transportation. Cases like also never occurred in the scope of the Ministry in the State,

This paper is presented in The $4^{\text {th }}$ International Conference on Maritime Education and Training October $8^{\text {th }}$, 2020, Makassar, Indonesia 
cases of violence by senior culminate in die of student IPDN / STPDN in the year 2003 on behalf Wahyu Hidayat, and the case of the death of Cliff Muntu in an institution that is the same in the year 2007 (Suyanto, JawaPos.com, 2017) [16].

The last case that caused the national public to be in a concussion was the case of the death of the officer of the Aviation Safety Engineering Academy (ATKP) Aldama Putra (19 years). Gunawan (2019) convey the cause trivial, simply because Aldama was not wearing a helmet at the time of driving, he then summoned and directed to one of the rooms then persecuted $[\mathrm{B}[$. Aldama was hit in the chest until he died (Tribunnews.com.2019). The case of the back adds to a long series of cases of death of a student of environmental in Ministry Transportation. The phenomenon of the "uniform" at various campuses in on the psychology known as bullying. Prasetyo explain that bullying is a behavior aggressive that done by a person or group against people or groups of others who do it repeatedly with a way to hurt it physically or mentally (Sufriani \& Sari, 2017) [4].

Bullying is behavior aggressive in dominant and cause damage or stress, behavior bias in physical as well as verbal (Messias, Kindrick, and Castro, 2014) [3]. Bullying behavior causes psychological, physical and emotional symptoms (Liu \& Graves, 2011) [5]. Impact negatively in the period of the short and long of the behavior of bullying such as depression, anxiety and the price of self-Low (King, et al., 2013).

In the research that others, discovered the effect of the stronger of the pattern of parenting to the tendency of aggression or harassment. Munawir (2016) [6] explains that the pattern of parenting that right is able to suppress the number of acts of aggressiveness in adolescents. Zazimah (2015) find that the pattern of parenting that authoritarian can improve behaviors aggressiveness [15]. While Ayesha (2010) explain that kind of pattern of parenting that can minimize the occurrence of aggressiveness ad ne patterns of parenting that is democratic.

PIP Makassar as a school high that uses the dorm, have caregivers are arranged in such a form to shape the character of cadets. Need to be traced, the type of pattern of parenting that when this takes place, is it already running effective or not. If not, need to be developed kind of pattern custody or approach to parenting that can educate cadets are positive.

\subsection{Focus Problems}

Based on the background behind that described in the above, the researchers propose focus a problem as follows:

1. Does the pattern of parenting in PIP Makassar considered already run effectively by cadets?

2. Characters what the time is obtained cadets of the pattern of parenting that is applied in the Environment PIP Makassar?

\subsection{Objectives of Research}

1. To determine whether the pattern of parenting that is applied in the environment PIP Makassar already running effective or not.

2. To determine the impact that appears on the attitudes and behavior of cadets with executable models of pattern foster the ideal. 


\subsection{Significance of Research}

1. In theory, expected to add to the repertoire of knowledge or develop insight, especially in terms of attitude and behavior of cadets and member input or information for faculty and staff education on PIP Makassar environment.

2. In practical terms,

1. For cadets

Provide knowledge to the cadets the importance of education in the era of globalization when it.

2. For Lecturers

As material for consideration and information for lecturers in knowing the extent to which the attitudes and behavior of cadets are formed.

3. For Institutions

As the material input and consideration as well as information in knowing how far the attitude and behavior of cadets were shown in school.

\section{Literature Review}

\subsection{Coaching}

Dormitories are entities that play a vital role in regulating the routine patterns of cadets. Apart from the family as the primary group, the situation in the dormitory is a place for cadets to get education and get to know the values and rules that they must follow as students. The situation that is formed in the dormitory will directly shape one's identity as a tough cadet and able to keep up with the development of ever-growing professional demands. The campus background occupied by cadets can be different in terms of educational models, experiences, and the dynamic development of the world of work, eventually there is a way or parenting style used in educating cadets. Santrock (2002) describe patterns of parenting as car A or the method used by caregivers to children foster that child custody can grow and develop into individuals who are good at putting themselves in socially [13].

Gunarsa (2000) describes the pattern of parenting as a way or method that deliberately chosen the caregiver in determining how caregivers treat the participant students [9]. Caregivers can only be parents or guardians, in this study the caregivers were senior coaches or cadets. Chabib Thoha (1996) explains that the coaching pattern is the best applied to the caregiver as a manifestation responsibility for her. Appropriate parenting will form a successor independent, mentally healthy, and can evolve with either intellectually, and spiritually [8].

Based on some of the explanations above, it can be concluded that parenting is a relationship between caregivers and foster participants with caregivers as parties who instill positive values that can stimulate the growth and development of foster participants' character. Caregivers have different approaches based on experience and environmental conditions that have taken place many years before.

\subsection{Types of Coaching}

According to Agus Dariyo (2004) parenting styles in foster care are divided into four, namely [10]:

a. Authoritarian Coaching (Coach oriented) This parenting system requires participants to obey all the rules given by the caregivers. Caregivers act arbitrarily, without the ability of participants to control. Foster participants in this version must follow all orders without being allowed to argue or even ask for reasons for orders received by 
foster participants. This strict binding rule makes participants limited in conveying their biased positive responses. This pattern can give birth to participants who are anxious, not confident, and inferior in social interactions. Another negative thing that can arise is that participants who are raised with authoritarian methods have the potential to engage in aggression in the future.

b. Permissive Coaching (children centered) On the approach pattern of foster care, the caregiver gives freedom to the participants foster rule. The caregivers allow the behavior and attitudes that are raised by the caregiver, all the participants' wishes are allowed. Caregivers tend to be arbitrary without being supervised by a tutor, free to do whatever they want. The negative effect of this parenting, foster participants can ignore the rules that exist in their environment. However, if the foster participants or foster children can carry out their wishes accompanied by responsibility, then the foster participants will grow independently and creatively, take initiative, and be able to realize the actualization positively.

c. Democratic Parenting This pattern illustrates that caregivers and foster children have an equal position. Rules and decisions are mutually agreed upon. Foster participants are given the freedom to do something and make decisions, but under the supervision of the tutor and the caregiver, they must be responsible for their choice of actions. Caregivers and guardians should not be doing act arbitrarily. Foster participants are given the confidence to be responsible. Effect positive of the pattern is that, child custody or participants will grow with the nature of trust toward others, honestly. However, the effect of negative allowed to appear namely, the authority of the caregiver bias shaken because decisions must always be taken in together.

d. Situational Parenting On the pattern of parenting, the sitter does not specify patterns of parenting particular. Caregivers only look at the situation in a flexible, relatively compromise, and always adjust to circumstances that took place when it was.

\subsection{Factors Affecting Parenting Patterns}

a. Parents Education Educator 's as well as the experience of caregivers in care in the past be the determining sensitivity of caregivers in view the growing process participants custody. Readiness patterns of parenting is supported by the material care received through formal and informal processes eg talk shows or seminars on the pattern of parenting.

b. Environment Environment is a variable outside themselves children as targets upbringing also gave contribution in the pattern of parenting applied by a caregiver. Environmental factors become a "fortress" that surrounds foster participants in accepting the care process from tutors.

c. Culture Factors see how a pattern of parenting are considered as a norm common that patterns of particular effective in doing parenting, while still growing. This cultural factor makes certain patterns that are considered effective continue to be passed on to the next generation.

\subsection{Theoretical Framework}

Parenting is one of the key factors that determine a person's character. Various kinds of patterns of parenting as a pattern of foster authoritarian, democratic, situational, and permissive each have advantages and disadvantages. In an educational environment with a dormitory concept, care is carried out by coaches and seniors in the caring process. Appropriate parenting can reduce degree of aggressiveness in adolescents (Munawir, 
2010) [6]. Parenting can improve the behavior of aggression is the type of pattern foster authoritarian (Zazimah, 2015) [15]. While Ayesha (2010) provide explanations that the aggressiveness can be suppressed by applying a pattern of foster democratic. Authoritarian parenting can lead to high compliance and discipline but can also result in defiance from foster participants and can repeat bad behavior that had happened to him when he was in a subordinate (junior) position. Conditions of Concern is mistake caregivers in applying the pattern of parenting, not to the character of firmness that was about to be given but one that appears is the attitude authoritarian finally took place in heritage next generations.

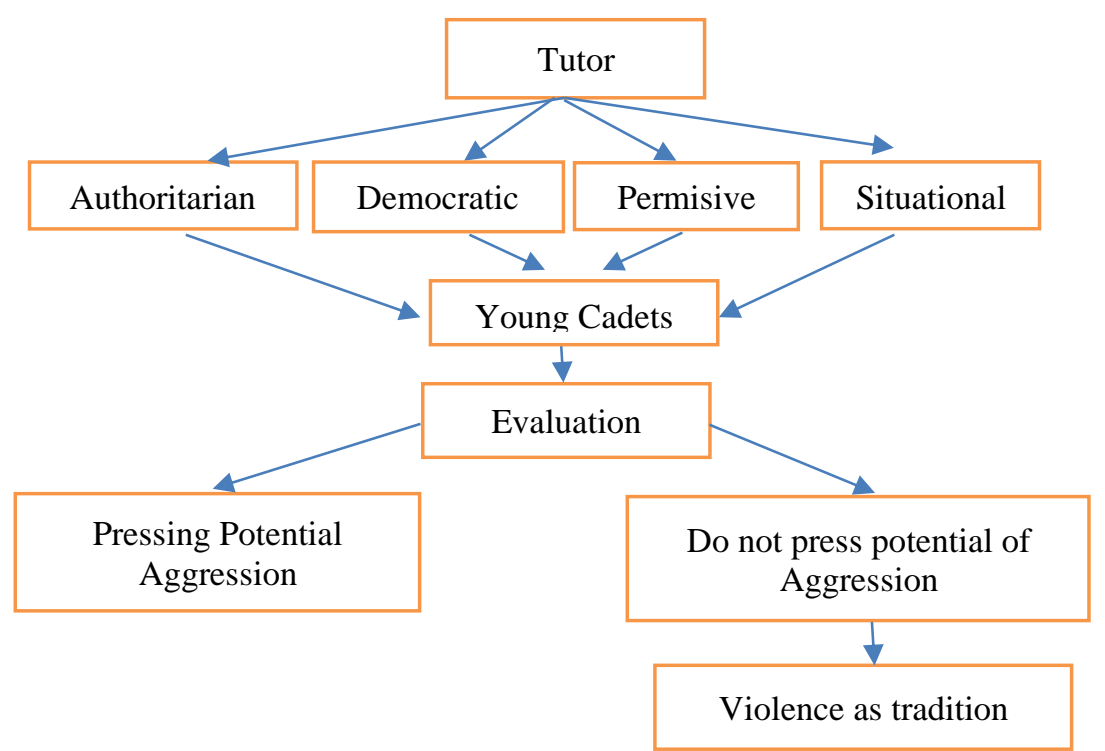

Figure 1. Framework

\section{Research Method}

\subsection{Approach}

Research that will do this using a qualitative research method. Poerwandari (2009) members of the explanation that qualitative produce and process the data that its descriptive, such as transcripts of interviews, notes field, images, photos, recordings, and video. Qualitative research trying to translate the views of basic interpretative and phenomenological. Creswell (2014) [14]. explains that a qualitative research method of research that is used to explore and strive to understand code through the collection of data on some individual or group of people from backgrounds phenomenon of social the same.

The reason the use of methods of qualitative in research by Sarantakos (Poerwandari, 2009) as follows: (1) the reality of the social are things that are subjective, and need to be interpreted. (2) humans are dynamic, trying to create a chain of meaning in living his life, not rigid to follow the laws of nature on the outside of yourself her. (3) science is based on everyday knowledge, is inductive, idiographical and not value-free, and (4) the purpose of the research is to try to understand social phenomenon. Step first that made investigators are interviewing in order to obtain information that in and naturally from the subject in accordance with the experience and how subjects interpret the conditions. Researcher observed that the subject in terms of cadets PIP experience the dynamics of psychological separately for lead role as cadets.

\subsection{Limitation of Terms}

The term limitation that will be explained in this research is the Coaching Pattern for Cadets. Coaching Pattern for cadets in research is that approaches to the care that is 
given to the cadets that formed his character as a youth that is competent and away from violence.

\subsection{Subject of Research}

Techniques that are used to choose subjects in research this is the technique of purposive sampling. Purposive sampling that is intended is the researcher determine his own subjects were taken for no consideration certain. Subject is not selected by random, but selected based on criteria that are determined by the investigators. Characteristics of subjects who at select by researchers are midshipman who has undergone the life of at least one semester of as cadets. Patton explained that take sample purposive in an attempt to find a diversity of variations of large data found through the subject. Researcher was not focused on efforts to identify problem-period was fundamental (Poerwandari, 2009) [12]. .Researchers will dig up as much information as possible from the subject to obtain the 'saturation point' of the object under study, Sarantakos (Poerwandari, 2009) [12]. The characteristics of the subjects were involved in the research is as follows

Table 1

\begin{tabular}{|c|c|c|c|c|}
\hline No. & Initials & Sex & Age & Semester \\
\hline 1 & MK & Women & $19^{\text {th }}$ & II \\
\hline 2 & RY & Male & 21 th & V \\
\hline 3 & OAK & Women & 21 th & VI \\
\hline 4 & FD & Male & 23 th & VI \\
\hline
\end{tabular}

\subsection{Research Location Settings}

The location of this research was conducted at campus II PIP Makassar. The main setting at the location is not determined, but is left natural so that the data obtained remains original and in-depth. Poerwandari (2009) states that in the research Qualitative research is natural, the researchers did not attempt to manipulate the setting of research, but rather conduct a study on a phenomenon which the phenomena are taking place [12].

\subsection{Data Collection Techniques}

The collection of data on research is used by using the interviews depth. Banister, et al (Poerwandari, 2009) states that Interview is a conversation and asked responsible are directed to achieve certain goals [12]. Interviews Qualitative do when researcher want to gain knowledge about the meaning of the subjective which is understood individuals with regard to the topic of the study, and intends to carry out exploration of the issues mentioned, a thing that is not able take through approaches other. The data that will be obtained by researchers through this interview used an interview approach with general guidelines. Patton (Poerwandari, 2009) states that the interview with the guidelines for the general who referred to is the researcher equipped with a guidance interview which is very common, which included only about the issues that want to be assessed without determining list questions, even perhaps without any form of question explicitly [12].

\subsection{Data Analysis}

Coding is step important that must be passed before doing the analysis of data. The data that has been obtained are then organized in a complete and detailed manner by providing codes that have specific meanings. The processes that will provide an overview of the topics are studied. The process that will deliver the researchers to discover the meaning of the data collected (Poerwandari, 2009) [12]. The steps that must be taken to do coding according to Poerwandari (2009) [12]. are as follows: 
1. The preparation of transcripts of interviews or verbatim ( word -by- word ) is positioned in the middle and then given a column that is empty in the next left or right of the transcript of the order into place to provide the code once observed .

2. Stages The second is the numbering is sequential in rows transcripts and or paint a tan field such. In a study this, researchers give a number se means sequentially in each paragraph new.

3. Researchers provide a name for each file with certain codes. The code that is selected is a code that is easily understood and remembered by researchers to facilitate the identification of the stage of analysis.

Example granting the code in the file: (WWC . FD2.297): Transcript of interview in-depth on the subject F D are carried out on an interview the second, on the line 297.

The next stage in analyzing the coding results is mentioned by Boyatzis (Poerwandari, 2009) as a systematic analysis. The data is already there still are random, the data are then grouped based its categories. After finding a pattern, ten classified by giving a label, definition or description. Thematic Analysis can be used to get the data corresponding level of needs of researchers. Analysis of Systematic is minimally able to describe the phenomena while in maximum will direct researchers to more easily interpret the phenomena were investigated.

\section{Results And Discussion}

\subsection{Result}

\subsubsection{Effectiveness of Parenting at PIP}

The fifth semester cadets and alumni provide an evaluation that the guidance pattern applied at PIP Makassar is good and in accordance with what is really needed as a sailor. The pattern is assertive, discipline, and demanded to be responsible is the pattern of development that will familiarize themselves cadets if already time was on the ship.

In technical, it is proposed to implement the proportion of caregivers who together with the institutions IPDN, which apply every two twenty cadets get one caregiver fixed, to make them easy to perform control of the cadet-midshipmen young. Cadets who receive touching punishment should also be accompanied by a campus caretaker from the elements of lecturers or marines, or at least the most senior cadets so that someone can control if junior level of cadets young give punishment exaggerated.

Also need to pay attention to the coaching tailored to the character of the generation of the millennial generation and $\mathrm{Z}$ generation is in a position as a cadet youth. While in development, cadets half above and alumni giving advice to managers, in terms of this campus so members of space over a lot of the cadets to explore themselves are positive through means sports, art, as well as facilitating the cadets who will follow various competitions across campus, both in Makassar and outside Makassar. It is also proposed that the campus noticed competence when it expanded beyond and into the demands of the new, to be adjusted by the materials and curriculum will be given to cadets who still while college.

\subsubsection{The characters that Cadets get}

\section{a) Tough}

Midshipman in PIP feel that the guide pattern obtained during this makes them feel powerful, in the sense of self, responsive, and not abstinence surrender. Cadets considers that resilience as a result of mental education is very relevant to the demands of a job as a sailor. Most cadets at the beginning of the semester considers the pattern of coaching in 
college too hard at the time a new entry, but when 've ever tasted straight practice on board, then feel that what obtained on campus is very useful.

"It can say properly, but when do implementation to us right over hard ship. So I said maybe the right way The seniors love this way, the right way. 3rd semester 4th semester climbed onboard his pass increasingly hard again and increasingly formed mental. So it is considered normal to be so-so "(Wwc. FD2.15) ". . . Initially it was, well there was a change, so see the upgrade, I mean see. . . per semester, it means there are changes, the steps in how we are treated .. " (Wwc. FD1.91) At the moment is in ship, the captain of the ship bias only make an order to cadet did not know the time, if done wrong, then the captain of the ship bias alone punish without ever predictable type of sentence. The situation that is felt very tiring if not ever be simulated through coaching in college.

\section{b) Self- Control}

Control yourself a character to next perceived obtained by the Youth. Control yourself it makes cadets feel more disciplined, able to manage emotions with a good when it became the target of orders from senior and captain of the ship, and is able to adapt to the situation naturally during the above vessels such as the condition of the weather and the character of the captain of the ship different. Cadets assume that cadets are being practical and not tough and not be able to do control herself with good, then the cadets are going to feel harassed if shouted for example by the captain of the ship during practice.

"Because the intention was warned to say silence. That is like do exist movement additional to the next this position more senior angry "(WWC. EK1.47)

"Then there was our NDA treated is already naturally or how is our intention bottom of the well. Definitely paced obey all must obey "(WWC. EK1. 155)

the rules over above the boat too much, or even feel that the rules for sailing was excessive, cadets who entered the category that can only give diving a practical and down from the ship and do not want anymore. Situations are recognized cadets ever done by the cadets who came from the campus of the cruise else other than PIP. Midshipman feel that the situation that makes ashamed campus and college alumni are concerned, therefore, the cadets must be ready to accept the pattern formation is applied on the campus, in order to feel more prepared if sailing later.

\section{c) Responsible}

Cadets feels that the pattern of guidance while on the PIP campus makes him feel more responsible for the decisions or choices that have been made. Character of responsibility is deemed cadets obtained when receiving punishment on mistakes that have been made. Midshipman feel that the guide pattern the system of administration of punishment at the time of the early half of the convicted are bulk if one don errors perceived make cadets are conditioned in order to realize his mistake and asked forgive to friends if had been doing wrong.

"Yes, personal responsibility . Kan that brought all the lecturers at officers also trouble senior at the professor " (Wwc.RY2.143)

"If at the point right actually seniors that punishment again, there is no saying like intention to harm" (Wwc.RY2.131) ". . if there is a problem yes definitely there are also penalties, problems with seniors, go, . ." (Wwc.RY1.143)".

If you gave the punishment in the first 'eeh it was certain, if I was sure it was snapped. Clay used his mental him to where. Keep hovering he work something that is in the one we love know her work. . . " (Wwc. FD2,297)

Then when he is in campus two, if he makes a mistake, he will definitely get a punishment such as holding a cruise or punishment for touching, making cadets reflect on 
their mistakes and try not to make similar mistakes again. Finally, in the choices taken by cadets going forward, always think about the consequences of the actions and attitudes chosen and if asked to be responsible, the cadets will be ready to take responsibility.

\subsection{Discussion}

Characters tough living in self-cadets this is the formation of neighborhood campus via pattern formation, a formidable described by Angela Duckworth (2007) [1] as behaviors that demonstrate perseverance, never give up, and high spirit in doing efforts systematically in order to achieve the purpose of term lengths expected. Explanation of the theoretical is also experienced by the cadets, trying to survive despite the pattern of parenting tight and hard to become a sailor reliable. More further described by Duckworth and Quinn (2019) that person have levels of toughness is different, it is caused because each individual has a personality different with various dynamics of the situation [2]. Individuals in this case cadets will achieve success if they have good tough power during their education as cadets.

Characters subsequent forming themselves cadets are control themselves or control themselves, Borba (2008) explains that the control of self is the ability of an individual to restrain himself from the desires of lust so that the individual behavior is behavior, thoughts, and the right heart [11]. Control yourself also means people aware of the consequences of hazards of receipt if not able to withstand the action and emotion with the good. Meanwhile, Thompson explained that self-control is an individual's belief that his ability to achieve the desired results depends on his own actions. Explanation of theoretical is found in self-cadets who, despite being tired and emotional, if the demands already arrived, the youth tried to control myself so was able to follow the directives that do not get the treatment that is not desirable, minimal such as punishment.

Cadets also get characters bear responsibility for trained on campus PIP Makassar, Rohmah (2016) describes responsibility is person awareness will act, whether intentional or not intentional [7]. Individuals who are responsible will act as awareness of the obligations. Individuals who do not want to be responsible will be forced by other parties to act according to that responsibility. Individuals who grew up with liver conscience will feel guilty if their actions make a loss the other. Responsibility can be grow by education, imitation, and understanding will piety to God Almighty.

\section{Conclusion And Suggestion}

\subsection{Conclusion}

1. Pattern formation during this already considered running effectively by cadets to form mental cadets as the sailors were professional. Cadets feel what that is obtained during the on campus can be applied during the sailing and cadets was already familiar with the condition that hard that exist in the upper vessel during sailing.

2. Characters are obtained from Pattern Guidance The pattern of development that during this took place in PIP Makassar has been considered both by cadets and graduates as capable of forming cadets and graduates into the private who has a character strong, has control themselves are good, and be responsible.

\subsection{Suggestion}

There are also suggestions given by researchers, namely:

1. PIP as campus implementation need to maintain the pattern of parenting that during this already takes place, there is no input from the cadets was their upbringing are 
proportionally between the coach who supervises directly some cadets to be able to stay away from acts of violence. Suggestions that are technical in nature outside of parenting problems, namely, increasing the chances of cadets participating in sports, arts, and academic competitions with other campuses.

2. For cadets, cadets can understand that the situation loudly that encountered in the environment dictionary is not to facilitate violence, but in order to be mentally cadets can be tough as a sailor.

\section{References}

[1] Duckworth, A.L, dkk. Grit : Perseverance and Passion for Long Term Goals. Journal of personality and Social Psychology. 2007; 92:1087-1101

[2] Duckworth, A.L \& Quinn, P.D. Development and Validation of Short Grit Scale (GritS). Journal of Personality Assesment. 2009; 91:166-174.

[3] Messias E, Kindrick K, Castro J. School bullying, cyberbullying, or both: correlates of teen suicidality in the 2011 CDC Youth Risk Behavior Survey. Comprehensive psychiatry. 2014; 1;55(5):1063-8.

[4] Sufriani, \& Sari, E.P. Faktor yang Mempengaruhi Bullying pada Anak Sekolah di Sekolah Dasar Kecamatan Syiah Kuala Banda Aceh. Idea Nursing Journal. 2017 ; VIII(3): 2017 ISSN : 2087-2879, e-ISSN : 2580 - 2445.

[5] Liu J, Graves N. Childhood bullying: A review zof constructs, concepts, and nursing implications. Public health nursing. 2011; Nov 1;28(6):556-68.

[6] Munawir, M. Dampak Perbedaan Pola Asuh terhadap Perilaku Agresif Remaja di SMA 5 Peraya. Jurnal Psychology \& Humanity. 2016; 1: 256-262.

[7] Rohmah, E. Y. Mengembangkan Karakter Tanggungjawab pada Pembelajar. Jurnal Al Murabbi. 2016; 3(1): July 2016.

[8] Thoha, Chabib. Kapita Selekta Pendidikan Islam, Yogyakarta: Pustaka pelajar (IKAPI). 1996.

[9] Gunarsa, S. D. Psikologi perkembangan anak dan remaja. Jakarta: Gunung Mulia. 2000.[I]

[10]Dariyo, Agoes. Psikologi Perkembangan Remaja. Jakarta: Ghalia Indonesia. 2004.

[11]Borba, M. Membangun kecerdasan moral, Tujuh kebajikan utama agar anak bermoral tinggi. Alih BahaSa: Lina Jusuf. Jakarta: PT. Gramedia Pustaka Utama. 2008

[12] Poerwandari, E. K.. Pendekatan kualitatif dalam penelitian perilaku manusia. Jakarta: Lembaga Pengembangan Sarana Pengukuran dan Pendidikan Psikologi (LPSP3) UI. .2009

[13] Santrock, J. W. (2002). Life Span Development (Perkembangan Masa Hidup). Jilid 1: Edisi Kelima. Jakarta: Penerbit Erlangga. 2002.

[14]Creswell, J. W. (2014). Research Design pendekatan kualitatif, kuantatif, dan mixed. Yogyakarta: Pustaka Pelajar. 2014.

[15]Zazimah. Pengaruh Pola Asuh Otoriter terhadap Tingkat Agresivitas Anak Usia 4-4 Tahun di RS Insan Harapan, Kec. Pandak, Kab. Bantul. Skripsi, Essay. Semarang: Universitas Negeri Semarang. 2015

[16] Suyanto, B. Sub Kultur Kekerasan di Sekolah Kedinasan. (JawaPos.com, acces on 11 April 2019).

[17] Gunawan, H. Taruna ATKP Tewas di Tangan Senior. (Tribunnews.com, acces on 8 April 2019). 